\title{
Investigation of enrofloxacin and ciprofloxacin residues by LC-MS/MS in chicken liver marketed in Afyonkarahisar
}

\author{
Damla ARSLAN-ACARÖZ1,a,®, Nalan BAYŞU SÖZBİLİR ${ }^{2, b}$ \\ ${ }^{1}$ Afyon Kocatepe University, Bayat Vocational School, Afyonkarahisar; ${ }^{2}$ Afyon Kocatepe University, Faculty of Veterinary \\ Medicine, Department of Biochemistry, Afyonkarahisar, Turkey.

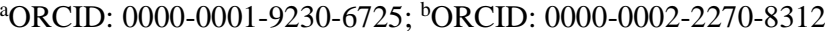

Corresponding author: darslan @ aku.edu.tr
Received date: 08.04.2019- Accepted date: 23.11 .2019

\begin{abstract}
Antibiotic residues can remain in animal source foods, mainly in the liver. Enrofloxacin (ENR) is a synthetic fluoroquinolone antimicrobial agent which is extensively used to treat bacterial infections in poultry. This study aimed to evaluate ENR and its main metabolite ciprofloxacin (CIP) occurrence in 100 chicken livers marketed Afyonkarahisar, Turkey. Chicken liver samples were analyzed by LC-MS/MS method with limits of detection for $1.17 \mu \mathrm{g} / \mathrm{kg}(\mathrm{ENR})$ and $1.24 \mu \mathrm{g} / \mathrm{kg}(\mathrm{CIP})$. ENR and CIP were detected in $39 \%$ and in $31 \%$ of samples, respectively. However, the total sum of both antibiotic residue levels was found to be far below the established maximum residue level $(200 \mu \mathrm{g} / \mathrm{kg})$ in all of chicken liver samples. In conclusion, according to the results of this study, chicken livers marketed in Afyonkarahisar city are safe for public health regarding ENR and CIP residues. Nonetheless, periodical control of chicken liver is advised due to the high incidence of these antibiotics.
\end{abstract}

Keywords: Antibiotic residue, chicken liver, ciprofloxacin, enrofloxacin, LC-MS/MS

\section{Afyonkarahisar'da satışa sunulan tavuk karaciğerlerinde enrofloksasin ve siprofloksasin kalıntılarının LC-MS/MS ile araştırılması}

Özet: Antibiyotik kalıntıları hayvansal orjinli gıdalarda özellikle karaciğerde bulunabilir. Enrofloksasin (ENR) sentetik bir florokinolon antimikrobiyal ajan olup kanatlılarda bakteriyel enfeksiyonların tedavisinde oldukça yaygın olarak kullanılmaktadır. Bu çalışmada Afyonkarahisar, Türkiye'de satışa sunulan 100 tavuk karaciğerinde ENR ve onun ana metaboliti olan siprofloksasin (CIP) varlığının araştırılması amaçlanmıştır. Tavuk karaciğer örnekleri LC-MS/MS metodu ile analiz edilerek, saptama limitleri ENR için $1,17 \mu \mathrm{g} / \mathrm{kg}$ ve CIP için 1,24 $\mu \mathrm{g} / \mathrm{kg}$ olarak belirlenmiştir. ENR ve CIP sırasıyla örneklerin \%39 ve \%31'inde saptanmıştır. Ancak, tavuk karaciğer numunelerinde her iki antibiyotik kalıntısının toplamı belirlenen maksimum kalıntı düzeyinin $(200 \mu \mathrm{g} / \mathrm{kg})$ oldukça altındadır. Sonuç olarak, Afyonkarahisar ilinde satışa sunulan tavuk karaciğerleri ENR ve CIP kalıntısı bakımından değerlendirildiğinde halk sağlığına risk oluşturmamaktadır. Bununla birlikte, bu antibiyotiklerin yüksek insidensi nedeniyle tavuk karaciğerinin periyodik olarak kontrol edilmesi tavsiye edilmektedir.

Anahtar sözcükler: Antibiyotik kalıntısı, enrofloksasin, LC-MS/MS, siprofloksasin, tavuk karaciğeri.

\section{Introduction}

Fluoroquinolones, essential drugs for human and animal health, are widely used for the treatment of several diseases in veterinary medicine $(21,24)$. Enrofloxacin (ENR), a common fluoroquinolone, has a broad spectrum of action and exhibits high efficacy against infectious diseases that are caused by mycoplasma and gram-positive and gram-negative bacteria $(14,21)$. Furthermore, this antibiotic is used in the treatment of common poultry infections, such as mycoplasmal infections, colibacillosis and pasteurellosis, due to its rapid oral absorption and long elimination half-life $(10,22)$. ENR shows its effect by interfering in the activities of bacterial DNA-gyrase and topoisomerase IV enzymes and, consequently, it inhibits bacterial DNA replication and transcription (5). Ciprofloxacin (CIP) is the main metabolite of ENR and occurs at different levels in foods of animal origin after the administration of ENR (12). Currently, the presence of contaminants in animal origin products is a major concern regarding food safety (16). Health problems can occur as a result of the excessive use of veterinary drugs in foodproducing animals because most of these substances may produce important toxic effects such as genotoxicity, carcinogenicity and immunotoxicity, as well as endocrine effects, on humans $(1,28)$. In addition, the improper use of ENR in food-producing animals and not respecting the 
necessary withdrawal time of this antibiotic may lead to residues in edible animal tissues. The presence of ENR residues in foodstuffs may cause allergic reactions in hypersensitive individuals and could lead to an increased pathogen resistance to clinical drugs in humans; therefore, they may represent important consequences for public health $(8,18)$. To protect food safety and consumer health, Maximum Residue Limits (MRL) have been established by the European Union for pharmacologically active compounds, including ENR. In chicken liver, the MRL is the total sum of ENR and CIP (200 $\mu \mathrm{g} / \mathrm{kg})$ (7). Therefore, if the residue levels in the target tissues are lower than the established MRL, the related food is considered safe regarding the presence of these antimicrobials (6).

The liver takes its place in the human diet owing to its fundamental nutritive value in providing dietary iron. However, it should be considered that the liver is a very complex organ due to its role in many drug metabolisms. Therefore, edible animal liver tissue must be monitored regularly regarding the presence of residues $(11,16)$. Chicken liver is one of the favorite foods of animal origin due to its high nutritional value and cheap price.

This study aimed to determine the levels of ENR and its metabolite CIP in chicken liver based on LC-MS/MS, with respect to the European Commission MRL.

\section{Material and Methods}

Chemicals and reagents: Methanol, formic acid, ENR and CIP were purchased from Sigma-Aldrich (St. Louis, MO, USA). All other reagents and chemicals were analytical grade and obtained from commercial sources.

Sample collection: A total of 100 chicken liver samples were obtained from Afyonkarahisar city, Turkey from September 2017-January 2018. Liver samples were purchased by supermarkets and local markets. The transportation of samples to the laboratory was performed under cold conditions $\left(+4^{\circ} \mathrm{C}\right)$ immediately after sampling and the collected samples were stored at $-20^{\circ} \mathrm{C}$ in a deep freezer until the analysis.

Standard solutions: ENR and CIP stock solutions were prepared at a concentration of $1 \mathrm{mg} / \mathrm{ml}$ in methanol. The working solutions were prepared from stock solutions to generate a calibration curve and to perform recovery studies of the chicken liver.

Sample preparation: Each liver sample was homogenized by a food blender and $5 \mathrm{~g}$ of sample was transferred into a polypropylene centrifuge tube $(50 \mathrm{ml})$ followed by addition of $10 \mathrm{ml}$ methanol and then the mixture was vigorously shaken for $5 \mathrm{~min}$. After the addition of $1 \%$ formic acid $(4 \mathrm{ml})$ and 0.01M EDTA (400 $\mu \mathrm{l})$, the centrifuge tube was vortexed for 3 and $2 \mathrm{~min}$, respectively. Subsequently, centrifugation of the mixture was performed at $2000 \mathrm{~g}$ for $10 \mathrm{~min}$ at $4^{\circ} \mathrm{C}$. After centrifugation, the supernatant of each sample was filtered through a membrane filter $(0.45 \mu \mathrm{m})$ and the obtained filtrate was transferred to a High Performance Liquid Chromatography (HPLC) vial for injection.

Instrumental conditions: The LC method described here was developed using an LC system of Agilent Technologies 1200 series (Waldbronn, Germany), combined to a binary high-pressure gradient pump. LC separation was performed by using Agilent Zorbax Eclipse XDB C18 column ( 4.6 x 30 mm x $3.5 \mu \mathrm{m})$. Mobile phase A consisted of water containing $0.1 \%$ formic acid while mobile phase B consisted of methanol containing $0.1 \%$ formic acid. The flow rate and injection volume of the mobile phases, and column temperature were 0.4 $\mathrm{ml} / \mathrm{min}, 10 \mu \mathrm{l}$, and $40^{\circ} \mathrm{C}$, respectively. LC separation gradient was set to $\mathrm{A} / \mathrm{B}(80 / 20)$ at $0.0 \mathrm{~min}$; it was changed to $\mathrm{A} / \mathrm{B}(10 / 90)$ and kept unchanged until $4.10 \mathrm{~min}, \mathrm{~A} / \mathrm{B}$ (80/20). MS analysis was conducted on Agilent 6460 LC/MS Triple Quadrupole instrument equipped with an ESI (Waldbronn, Germany) in positive ion mode. MS parameters of drying gas temperature, nebulizer gas, sheath gas flow, capillary voltage and sheath gas temperature were set to $350^{\circ} \mathrm{C}, 40$ p.s.i., $10 \mathrm{l} / \mathrm{min}, 4000 \mathrm{~V}$, and $400{ }^{\circ} \mathrm{C}$, respectively. Precursor ion and productions of ENR were 360, 342, and 316, respectively while precursor ion and productions of CIP were 332, 231 and 314, respectively.

Quality parameters of method: The validation of this method was performed by spiking chicken liver samples and limit of detection (LOD), the limit of quantification (LOQ), linearity range, intra- and inter-day precision and recovery were used as quality parameters. The concentrations of the samples were calculated according to the calibration curve method for which a series of external standard solutions are prepared and measured. For the calibration equation, a line is fitted to these data and the obtained equation is employed to calculate the concentration unknown samples. In addition, the strength of the linear regression is expressed with a correlation coefficient $\left(\mathrm{r}^{2}\right)$. These parameters were calculated by the software (Agilent MassHunter Workstation Software Version 7) of the analytical instrument. The lowest concentration of ENR or CIP that the analytical process can reliably differentiate from background levels (signal-to-noise ratio $\geq 3$ ) and lowest concentration of ENR or CIP that can be quantified (signal-to-noise ratio $\geq 10$ ) were defined as LOD and LOQ, respectively.

\section{Results}

ENR and CIP in chicken liver samples were quantified by LC-MS/MS. The typical chromatogram and standard calibration curves of ENR and CIP are shown in Figure 1 and Figure 2. LOD, LOQ, calibration curve parameters and retention times are shown in Table 1. Relative standard deviations used for precision and intra- 
and inter-day recoveries used for the accuracy of the method are given in Tables 2 and 3. The results of the present study show that $39 \%$ of all chicken liver samples $(n=100)$ were contaminated with ENR while $31 \%$ of chicken liver samples contained CIP (Table 4). Additionally, the highest concentrations of ENR and CIP were determined to be 30.23 and $6.92 \mu \mathrm{g} / \mathrm{kg}$, respectively.

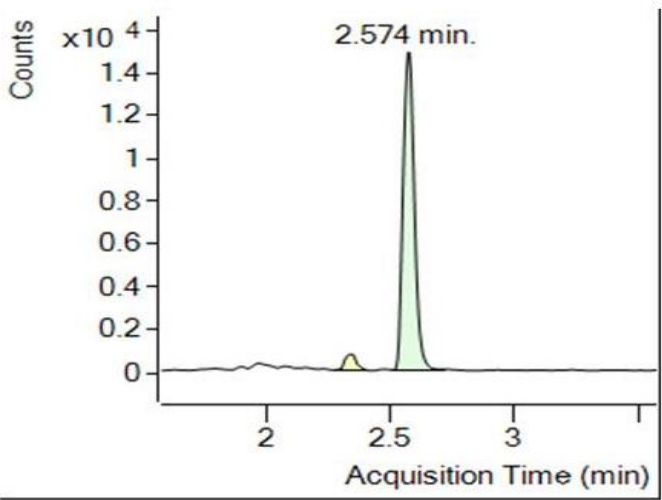

A

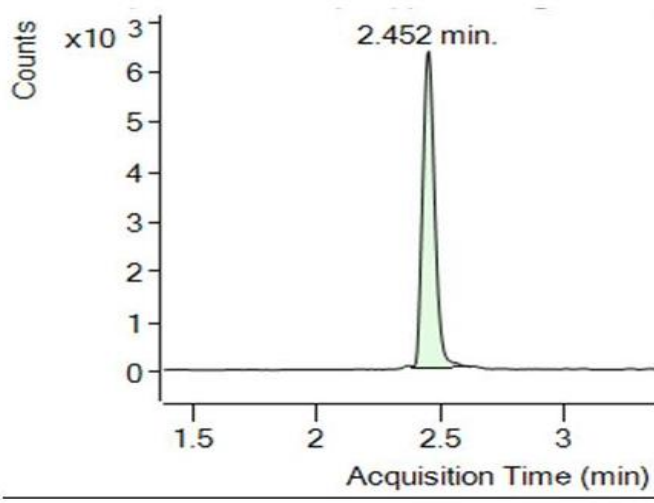

B

Figure 1. Chromatograms of enrofloxacin (A) and ciprofloxacin (B).
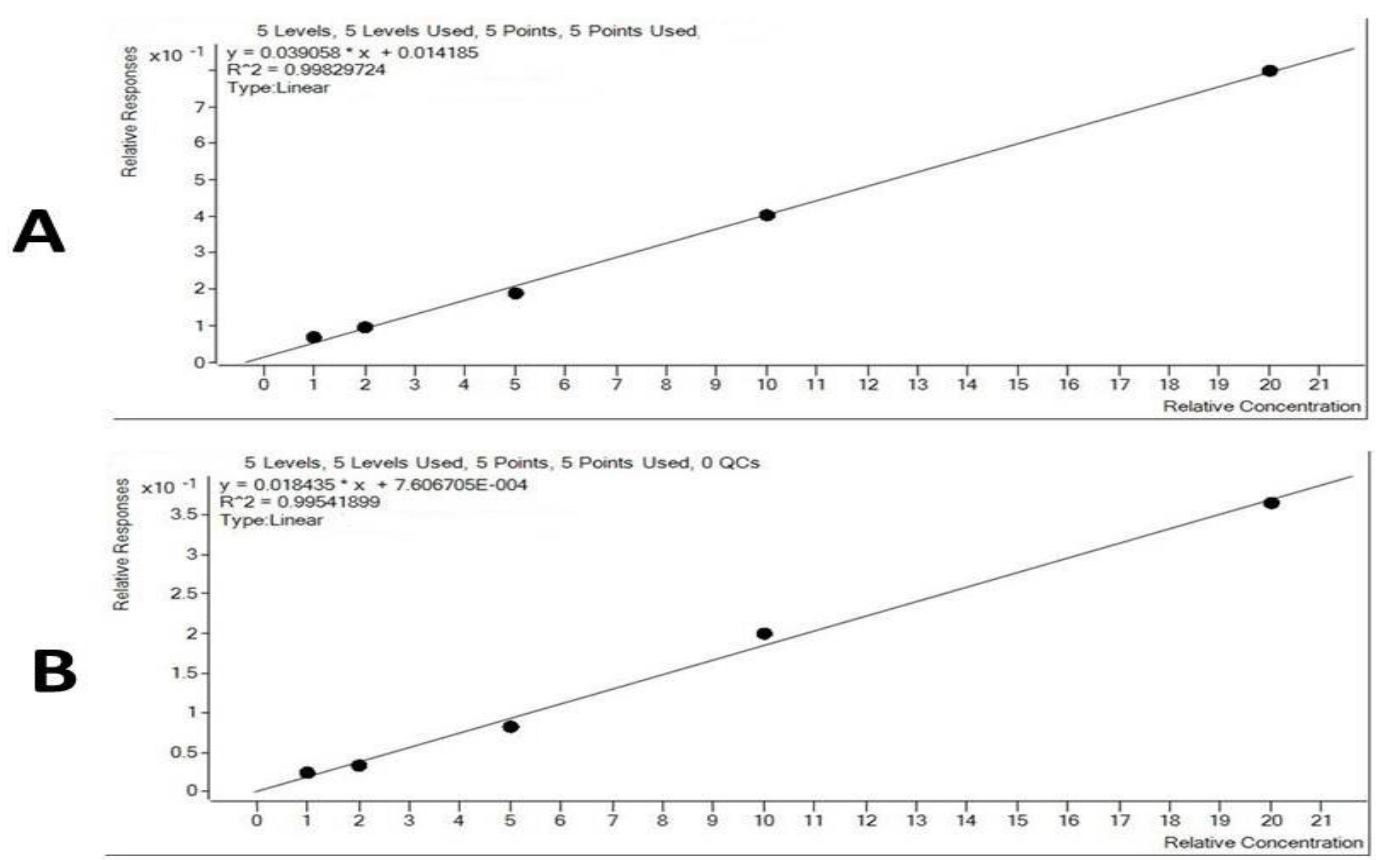

Figure 2. Standard calibration curves of enrofloxacin (A) and ciprofloxacin (B).

Table 1. Analytical parameters of enrofloxacin and ciprofloxacin in chicken livers.

\begin{tabular}{lccccccc}
\hline Antibiotic & $\begin{array}{c}\text { LOD } \\
(\boldsymbol{\mu g} / \mathbf{k g})\end{array}$ & $\begin{array}{c}\text { LOQ } \\
(\boldsymbol{\mu g} / \mathbf{k g})\end{array}$ & $\begin{array}{c}\text { Correlation } \\
\text { coefficient }\left(\mathbf{r}^{2}\right)\end{array}$ & $\begin{array}{c}\text { Calibration } \\
\text { equation }\end{array}$ & $\begin{array}{c}\text { Data } \\
\text { point }\end{array}$ & $\begin{array}{c}\text { Linear range } \\
(\boldsymbol{\mu g} / \mathbf{k g})\end{array}$ & RT $(\mathbf{m i n})$ \\
\hline Enrofloxacin & 1.17 & 3.90 & 0.995 & $\begin{array}{c}\mathrm{y}=0.039058 \mathrm{x} \\
+0.014185\end{array}$ & 5 & $1-20$ & 2.57 \\
Ciprofloxacin & 1.24 & 4.14 & 0.998 & $\begin{array}{c}\mathrm{y}=0.018435 \mathrm{x} \\
+7.606705\end{array}$ & 5 & $1-20$ & 2.45 \\
\hline
\end{tabular}


Table 2. Intra- and inter-day precisions for enrofloxacin in chicken liver samples.

\begin{tabular}{lccccc}
\hline Enrofloxacin & \multicolumn{2}{c}{ Intra-day assays $(\mathbf{n = 1 0})$} & & \multicolumn{2}{c}{ Inter-day assays (n=14) } \\
\cline { 2 - 3 } \cline { 5 - 6 } Spiked $(\boldsymbol{\mu g} / \mathbf{k g})$ & $\begin{array}{c}\text { Percentage } \\
\text { Recovery } \pm \mathbf{C V}\end{array}$ & $\mathbf{R S D}$ & & Percentage & RSD \\
& $97.86 \pm 1.87$ & 1.91 & & Recovery $\pm \mathbf{C V}$ & $(\boldsymbol{\%})$ \\
\hline 40 & $90.70 \pm 2.86$ & 3.15 & & $99.30 \pm 5.23$ & 5.27 \\
80 & $92.87 \pm 2.55$ & 2.75 & & $90.21 \pm 4.51$ & 4.51 \\
160 & & & $90.71 \pm 2.38$ & 2.62 \\
\hline
\end{tabular}

Table 3. Intra- and inter-day precisions for ciprofloxacin in chicken liver samples.

\begin{tabular}{lccccc}
\hline Ciprofloxacin & \multicolumn{2}{c}{ Intra-day assays $(\mathbf{n}=\mathbf{1 0})$} & & \multicolumn{2}{c}{ Inter-day assays $(\mathbf{n}=\mathbf{1 4})$} \\
\cline { 2 - 3 } \cline { 5 - 6 } Spiked $(\boldsymbol{\mu g} / \mathbf{k g})$ & $\begin{array}{c}\text { Percentage } \\
\text { Recovery } \pm \mathbf{C V}\end{array}$ & $\mathbf{R S D}$ & & Percentage & RSD \\
& $93.78 \pm 3.07$ & 3.28 & & Recovery $\pm \mathbf{C V}$ & $(\boldsymbol{\%})$ \\
\hline 40 & $89.19 \pm 4.49$ & 5.03 & & $94.48 \pm 4.66$ & 4.94 \\
80 & $94.00 \pm 2.44$ & 2.6 & & $88.13 \pm 4.87$ & 4.87 \\
160 & & & $91.47 \pm 1.63$ & 1.78 \\
\hline
\end{tabular}

Table 4. The enrofloxacin and ciprofloxacin levels of chicken liver samples $(n=100)$.

\begin{tabular}{llcccc}
\hline Enrofloxacin & Range $(\boldsymbol{\mu g} / \mathbf{k g})$ & $<1.17$ & $1.17-9.99$ & $10-19.99$ & $20-35$ \\
& Number of samples & 61 & 30 & 6 & 3 \\
\hline Ciprofloxacin & Range $(\boldsymbol{\mu g} / \mathbf{k g})$ & $<1.24$ & $1.24-1.99$ & $2-3.99$ & $4-7$ \\
& Number of samples & 69 & 13 & 11 & 7 \\
\hline
\end{tabular}

Table 5. Previous studies investigating the presence of quinolone-residues in chicken livers.

\begin{tabular}{|c|c|c|c|c|c|c|}
\hline References & Country & Analyze & Samples size & Positive (\%) & Range ( $\mu \mathrm{g} / \mathrm{kg})$ & Method \\
\hline Attari et al. (5) & Iran & ENR & 20 & $17(85 \%)$ & $5.30-90.7$ & ELISA \\
\hline Salehzadeh et al. (23) & Iran & ENR & 90 & $90(100 \%)$ & $4.3-66.2$ & HPLC \\
\hline \multirow[t]{2}{*}{ Rezaee et al. (22) } & Iran & ENR & 50 & $26(52 \%)$ & $16.7-296.7$ & HPLC \\
\hline & & CIP & & $15(30 \%)$ & $9.8-93.3$ & \\
\hline Aslam et al. (4) & Pakistan & ENR & 75 & $59(78.7 \%)$ & $527^{\mathrm{b}}$ & HPLC \\
\hline \multirow[t]{2}{*}{ Naeem et al. (19) } & Pakistan & ENR & 40 & $37(92 \%)$ & $3.02-364$ & HPLC \\
\hline & & CIP & & $34(85 \%)$ & $2.08-245$ & \\
\hline Younus et al. (30) & Pakistan & ENR & 45 & $40(88.8 \%)$ & $1.409^{\mathrm{a}}$ & ELISA \\
\hline \multirow[t]{2}{*}{ Sattar et al. (26) } & Bangladesh & ENR & 50 & $20(40 \%)$ & - & TLC \\
\hline & & CIP & & $22(44 \%)$ & - & \\
\hline Sarker et al. (25) & Bangladesh & ENR & 160 & $57(36 \%)$ & - & TLC \\
\hline Faten et al. (9) & Egypt & CIP & 15 & $13(86.7 \%)$ & $96.33-300.27$ & HPLC \\
\hline Sultan (27) & Iraq & ENR & 30 & $10(33.31 \%)$ & $0.01-10.69$ & ELISA \\
\hline $\begin{array}{l}\text { Nizamlıoglu and Aydın } \\
\text { (20) }\end{array}$ & Turkey & $\begin{array}{l}\text { CIP, DAN, DIF, } \\
\text { ENR, FLU, MAR, } \\
\text { OA, SAR }\end{array}$ & 50 & $17(34 \%)$ & $18.5-147.88$ & ELISA \\
\hline Metli et al. (17) & Turkey & $\begin{array}{c}\text { CIP, DAN, DIF, } \\
\text { ENR, FLU, MAR, } \\
\text { NA, NOR, OA, } \\
\text { SAR }\end{array}$ & 34 & - & - & $\begin{array}{c}\text { LC- } \\
\text { MS/MS }\end{array}$ \\
\hline \multirow[t]{2}{*}{ This Study } & Turkey & ENR & 100 & $39(39 \%)$ & $1.42-30.23$ & $\begin{array}{c}\text { LC- } \\
\text { MS/MS }\end{array}$ \\
\hline & & CIP & & $31(31 \%)$ & $1.25-6.92$ & \\
\hline
\end{tabular}

${ }^{a}$ Mean concentration, Ciprofloxacin (CIP), Danofloxacin (DAN), Difloxacin (DIF), Enrofloxacin (ENR), Flumequine (FLU), Marbofloxacin (MAR), Nalidixic Acid (NA), Norfloxacin (NOR), Oxolinic Acid (OA), Sarafloxacin (SAR) 


\section{Discussion and Conclusion}

Poultry meat and giblets, including liver, are widely consumed throughout the world. However, the liver is considered a highly risky poultry product due to its role in the detoxification of toxic substances, including antibiotics $(2,13,15)$. Quinolones are powerful options among the antimicrobial agents employed in the treatment of various bacterial-caused poultry diseases (29). In addition, the presence of quinolones in poultry products causes public health concerns (21). Local and international regulatory and public health agencies give attention to screening of antibiotic residues in foodproducing animals. In Turkey, National Residue Monitoring Plan is established to determine the presence of these substances including quinolone residues in foods of animal origin (3). Several monitoring studies conducted in different countries to investigate the presence of quinolone residues in chicken liver based on various methods (Table 5). Some of them reported very high incidence for quinolone residues in Pakistan $(4,19,30)$, Iran $(5,23)$ and Egypt (9). Attari et al. (5) reported that in $85 \%$ of 20 chicken liver samples collected from the Northwestern part of Iran, the ENR residue level ranged from 5.30 to $90.70 \mu \mathrm{g} / \mathrm{kg}$, with a mean concentration of $39.54 \mu \mathrm{g} / \mathrm{kg}$. In another study conducted in Iran using HPLC, a high contamination level (100\%) was reported for 90 chicken liver samples in a range from 4.3 to 66.2 $\mu \mathrm{g} / \mathrm{kg}$ (23). Similarly, Faten et al. (9) found, using HPLC, that $86.7 \%$ of 15 chicken liver samples marketed in Egypt tested positive for CIP at concentrations between 96.33 and $300.27 \mu \mathrm{g} / \mathrm{kg}$. Our results are lower than these studies. However, the findings of our study are in consistent with other studies for those incidence of quinolone-residues ranged from $33.31 \%$ to $44 \%(20,26,27)$. Sattar et al. (26) performed a monitoring study in Bangladesh based on thin-layer chromatography (TLC) and found contamination levels in chicken liver samples of $40 \%$ and $44 \%$ for ENR and CIP, respectively. In another study conducted in Iraq, ENR incidence reported as $33.31 \%$ while ENR level ranged from $0.01 \mu \mathrm{g} / \mathrm{kg}$ to $10.69 \mu \mathrm{g} / \mathrm{kg}$. Nizamlıoğlu and Aydın (20) evaluated a total of 50 chicken liver samples regarding the presence of quinolone-residues based on ELISA method and reported that $34 \%$ samples contained quinolones. Additionally, in a study conducted in Antakya province of Turkey, chicken liver samples were collected from 34 different markets and analyzed regarding 38 antibiotic residues and none of the samples have quinolone residues (17). Our results are not compatible with this study. In the present study, the ENR contamination level was found to be between 1.42 and $30.23 \mu \mathrm{g} / \mathrm{kg}(39 \%)$, and the CIP contamination level was found to be between $1.25-6.92 \mu \mathrm{g} / \mathrm{kg}(31 \%)$. According to the results of the present study, the total sum of ENR and CIP did not exceed the established MRL in any of the chicken samples. Taken together, different incidences of quinolone-residues may be due to misuse or overuse of these antibiotics or disrespect of withdrawal time during poultry breeding.

In conclusion, poultry meat and meat products are extensively consumed throughout the world owing to their nutritive value and suitable price. However, antibiotic residues in foods of animal origin are an important public health issue. Therefore, monitoring programs for veterinary drug residues in these types of foods have been performed by national authorities. This study contributes to those residue monitoring programs by providing a highly sensitive and accurate LC-MS/MS method for chicken liver samples.

\section{Financial Support}

The authors thanks to the Scientific Research Council of Afyon Kocatepe University due to financial support to this study (Project no: 17.C.140).

\section{Conflict of Interest}

The authors declared that there is no conflict of interest.

\section{References}

1. Acaroz U, Arslan-Acaroz D, Gurler Z (2016): immunoassay development for the detection of antibiotic residues in foods. Kocatepe Vet J, 9, 122-126.

2. Acaroz U, Gurler Z, Kara R, et al (2018): Presence of Salmonella spp. in chicken meat and giblets marketed in Afyonkarahisar province. Kocatepe Vet J, 11, 1-5.

3. Anonymus (2019): Kalıntı izleme planı. Available at https://www.tarimorman.gov.tr/Konular/ Gida-Ve-YemHizmetleri/Gida-Hizmetleri/Kalinti-Izleme. (Accessed Sept 09, 2019).

4. Aslam B, Kousar N, Javed I, et al (2016): Determination of enrofloxacin residues in commercial broilers using high performance liquid chromatography. Int J Food Prop, 19, 2463-2470.

5. Attari VE, Abbasi MM, Abedimanesh N, et al (2014): Investigation of enrofloxacin and chloramphenicol residues in broiler chickens carcasses collected from local markets of Tabriz, Northwestern Iran. Heal Promot Perspect, 4, 151157.

6. Bonassa KPD, Miragliotta MY, Simas RC, et al (2017): Tissue depletion study of enrofloxacin and its metabolite ciprofloxacin in broiler chickens after oral administration of a new veterinary pharmaceutical formulation containing enrofloxacin. Food Chem Toxicol, 105, 8-13.

7. EU COMMISSION REGULATION (2010): No 37/2010 of 22 December 2009 on pharmacologically active substances and their classification regarding maximum residue limits in foodstuffs of animal origin.

8. Fàbrega A, Sánchez-Céspedes J, Soto S, et al (2008): Quinolone resistance in the food chain. Int J Antimicrob Agents, 31, 307-315.

9. Faten SH, Mousa MM, Mahomud AH, et al (2016): Ciprofloxacin residues in chicken and turkey carcasses. Benha Vet Med J, 31, 136-143. 
10. Gbylik-Sikorska M, Posyniak A, Sniegocki T, et al (2016): Influence of enrofloxacin traces in drinking water to doxycycline tissue pharmacokinetics in healthy and infected by Mycoplasma gallisepticum broiler chickens. Food Chem Toxicol, 90, 123-129.

11. Kaufmann A, Butcher P, Maden K (2012): Determination of aminoglycoside residues by liquid chromatography and tandem mass spectrometry in a variety of matrices. Anal Chim Acta, 711, 46-53.

12. Kirbis A, Marinsek J, Flajs VC (2005): Introduction of the HPLC method for the determination of quinolone residues in various muscle tissues. Biomed Chromatogr, 19, 259265.

13. Kirrella GAK, Deeb AMM, Abdallah RMI (2017): Safety of frozen liver for human consumption. J Food Drug Anal, 25, 520-524.

14. Lolo M, Pedreira S, Miranda JM, et al (2006): Effect of cooking on enrofloxacin residues in chicken tissue. Food Addit Contam, 23, 988-993.

15. Magdelaine P, Spiess MP, Valceschini E (2008): Poultry meat consumption trends in Europe. Worlds Poult Sci J, 64, 53-63.

16. Martins MT, Barreto F, Hoff RB, et al (2015): Determination of quinolones and fluoroquinolones, tetracyclines and sulfonamides in bovine, swine and poultry liver using LC-MS/MS. Food Addit Contam - Part A Chem Anal Control Expo Risk Assess, 32, 333-341.

17. Metli M, Yakar Y, Tekeli Y (2015): Determination of antibiotic residues in chicken liver by liquid chromatography-tandem mass spectrometry. Adiyaman Uni J Sci, 5, 120-131.

18. Moema D, Nindi MM, Dube S (2012): Development of a dispersive liquid-liquid microextraction method for the determination of fluoroquinolones in chicken liver by high performance liquid chromatography. Anal Chim Acta, 730, 80-86.

19. Naeem M, Khan K, Rafiq S (2006): Determination of residues of quinolones in poultry products by high pressure liquid chromatography. J Appl Sci, 6, 373-379.
20. Nizamlığlu F, Aydın H (2012): Quinolone antibiotic residues in raw milk and chicken liver in Konya. Eurasian $\mathrm{J}$ Vet Sci, 28, 154-158.

21. Panzenhagen PHN, Aguiar WS, Gouvêa R, et al (2016): Investigation of enrofloxacin residues in broiler tissues using ELISA and LC-MS/MS. Food Addit Contam - Part A Chem Anal Control Expo Risk Assess, 33, 639-643.

22. Rezaee N, Rafie S, Javadi A, et al (2018): Determination of enrofloxacin and ciprofloxacin residues in five different kinds of chicken tissues by dispersive liquid - liquid microextraction coupled with hplc. Iran J Pharm Res, 17, 1182-1190.

23. Salehzadeh F, Salehzadeh A, Rokni N, et al (2007): Enrofloxacin residue in chicken tissues from Tehran slaughterhouses in Iran. Pakistan J Nutr, 6, 409-413.

24. San Martin B, Cornejo J, Lapierre L, et al (2010): Withdrawal time of four pharmaceutical formulations of enrofloxacin in poultry according to different maximum residues limits. J Vet Pharmacol Ther, 33, 246-251.

25. Sarker YA, Hasan MM, Paul TK, et al (2018): Screening of antibiotic residues in chicken meat in Bangladesh by thin layer chromatography. J Adv Vet Anim Res, 5, 140.

26. Sattar S, Hassan MM, Islam SKMA, et al (2014): Antibiotic residues in broiler and layer meat in Chittagong district of Bangladesh. Vet World, 7, 738-743.

27. Sultan IA (2014): Detection of Enrofloxacin Residue in Livers of Livestock Animals Obtained from a Slaughterhouse in Mosul City. J Vet Sci Technol, 5, 2-4.

28. Toldrá F, Reig M (2006): Methods for rapid detection of chemical and veterinary drug residues in animal foods. Trends Food Sci Technol, 17, 482-489.

29. Trouchon T, Lefebvre S (2017): A Review of enrofloxacin for veterinary use. Open J Vet Med, 6, 40-58.

30. Younus M, Abbas T, Zafar M, et al (2017): Quantification of enrofloxacin residues in broiler chicken tissues using competitive enzyme-linked immunosorbent assay. Indian $\mathrm{J}$ Anim Sci, 87, 659-661. 